\title{
Leptin upregulates COX-2 and its downstream products in aortic endothelial cells
}

\author{
YUELIN CHEN $^{1 *}$, YUECHUN SHEN $^{2 *}$, YA NIE $^{2}$, ZHONGXIN CHEN $^{1}$, \\ HUANG WANG ${ }^{2}$, HUANG LIAO ${ }^{2}$ and $\mathrm{JUN} \mathrm{LI}^{3}$ \\ ${ }^{1}$ Department of Cardiology, Affiliated Zhongshan Hospital of Guangdong Medical University, Zhongshan, Guangdong 528415; \\ Departments of ${ }^{2}$ Cardiology and ${ }^{3}$ General Surgery, The First Affiliated Hospital of Guangzhou Medical University, \\ Guangzhou, Guangdong 510120, P.R. China
}

Received November 15, 2016; Accepted June 22, 2017

DOI: $10.3892 /$ etm.2017.5177

\begin{abstract}
The adipocyte-derived hormone leptin is associated with hypertension. The involvement of cyclooxygenase-2 (COX-2) and its downstream vasomotor products prostaglandin (PG) and thromboxane (TX) $\mathrm{A}_{2}$ in the mechanisms of action of leptin have remained elusive. The aim of the present study was to investigate the effects of leptin on the expression of COX-2 by rat aortic endothelial cells (RAECs) and the concentration of its products, represented by 6-keto $\mathrm{PGF}_{1 \alpha}$ and $\mathrm{TXB}_{2}$, in the culture media. RAECs were isolated, cultured and identified by immunofluorescence staining. The RAECs were incubated with different concentrations of leptin $\left(10^{-10}\right.$, $10^{-9}$ and $10^{-8} \mathrm{M}$ ) for various durations (36 or $48 \mathrm{~h}$ ). COX-2 mRNA and protein expression in the cells was detected by reverse-transcription quantitative PCR and western blot analysis, respectively. The vasodilator 6-keto $\mathrm{PGF}_{1 \alpha}$ and the vasoconstrictor $\mathrm{TXB}_{2}$ were detected in the supernatant by ELISA. The cultured cells displayed specific factor VIII expression in the cytoplasm. Compared with the PBS-treated control group, leptin significantly increased the expression of COX-2 mRNA and protein in a time- and dose-dependent manner $(\mathrm{P}<0.01)$. Furthermore, the vasodilator 6-keto $\mathrm{PGF}_{10}$ was increased and the $\mathrm{TXB}_{2} / 6$-keto $\mathrm{PGF}_{1 \alpha}$ ratio decreased only with relatively high concentrations of leptin $\left(10^{-9}\right.$ or $\left.10^{-8} \mathrm{M} ; \mathrm{P}<0.01\right)$, but $\mathrm{TXB}_{2}$ levels were not affected $(\mathrm{P}>0.05)$. In conclusion, leptin significantly increased the expression of inflammatory marker $\mathrm{COX}-2$ and its downstream product 6-keto $\mathrm{PGF}_{1 \alpha}$, while also decreasing the $\mathrm{TXB}_{2} / 6$-keto $\mathrm{PGF}_{10}$
\end{abstract}

Correspondence to: Dr Jun Li, Department of General Surgery, The First Affiliated Hospital of Guangzhou Medical University, 151 Yanjiangxi Road, Guangzhou, Guangdong 510120, P.R. China E-mail: jun-li621120@163.com

*Contributed equally

Key words: leptin, endothelial cells, cyclooxygenase-2, prostacyclin, thromboxane ratio in vitro. These observations suggested that COX-2 may have an important role in the effects of leptin on inflammation, such as the low-inflammatory disease hypertension. However, selective COX-2 inhibitors may increase the risk of hypertension due to inhibiting 6-keto $\mathrm{PGF}_{1 \alpha}$, the vasodilator product of COX-2.

\section{Introduction}

Leptin, almost exclusively synthesized and secreted by white adipocytes, is a protein hormone encoded by the obesity (OB) gene. Its main function is to target the hypothalamic arcuate nucleus, resulting in the suppression of appetite and increase of energy consumption so as to regulate the energy balance (1).

Leptin receptors are widely expressed in cardiovascular tissues, including endothelial cells (ECs) (2). Therefore, leptin also targets arterial ECs, and is involved in the occurrence and development of hypertension (3), which it may achieve through causing EC dysfunction (4) and inflammation (5) as well as increasing the expression of endothelin-1 (6). In addition, leptin enhances endothelial-dependent vasorelaxation by upregulating the expression of neuronal nitric oxide synthase (nNOS) (7) and endothelium-derived hyperpolarizing factor (EDHF) (8). These opposite roles of leptin make it necessary to further study the expression of factors by ECs in association with hypertension regulated by leptin.

Cyclooxygenases (COXs) are rate-limiting enzymes, which catalyze free arachidonic acid and synthetize prostaglandin (PG) $\mathrm{H}_{2}$, which is further converted to prostacyclin $\left(\mathrm{PGI}_{2}\right)$ and thromboxane (TX)A $\mathrm{A}_{2}$. Among the COXs, COX-2 is an inducible enzyme whose expression is low in ECs under physiological conditions. The expression of COX-2 increases during pathological conditions of inflammation, such as hypertension, a lower-grade inflammatory disease. The downstream products of $\mathrm{COX}-2, \mathrm{PGI}_{2}$ and $\mathrm{TXA}_{2}$, affect vasomotion and platelet aggregation (9). However, the expression of COX-2 and its downstream products involved in hypertension induced by leptin has remained to be clarified.

The purpose of the present study was to investigate the expression of COX-2 and its downstream products $\mathrm{PGI}_{2}$ and TXA 2 (represented by 6-keto $\mathrm{PGF}_{1 \alpha}$ and $\mathrm{TXB}_{2}$, respectively) induced by leptin in vitro, so as to further understand the 
mechanisms of the involvement of leptin in hypertension, or to obtain information on the influence of leptin on systolic and/or diastolic function of blood vessels. The findings partially explained the mechanisms by which leptin mediates hypertension and put forward precautions from the aspect of medication use in hypertension.

\section{Materials and methods}

Experimental animals. A total of 8 male Wistar rats were purchased from the Experimental Animal Center of Sunyat-sen University (Guangzhou, China). All rats were between 4 and 5 weeks of age and fed normal chow in specific pathogen-free facilities. All animal protocols were approved by the Institutional Animal Care and Use Committee of the First Affiliated Hospital of Guangzhou Medical University (Guangzhou, China).

Isolation and culture of rat aortic endothelial cells (RAECs). Wistar rats were anesthetized by an intraperitoneal injection of pentobarbital (300 mg/100 g; Sigma-Aldrich; Merck $\mathrm{KGaA}$, Darmstadt, Germany) resulting in euthanasia. Aortic separation was performed as described previously (10). RAECs were isolated from aortic strips by the method of mixed enzyme digestion $[0.1 \%$ type II collagenase $(4 \mathrm{ml})$ and $0.1 \%$ trypsin $(4 \mathrm{ml}$; Gibco; Thermo Fisher Scientific, Inc., Waltham, MA, USA) digested for $20 \mathrm{~min}$ separately]. Cells were grown in Dulbecco's modified Eagle's medium containing $10 \%$ fetal bovine serum (both from Gibco; Thermo Fisher Scientific, Inc.), $1 \%$ penicillin/streptomycin and $100 \mu \mathrm{g} / \mathrm{ml}$ endothelial cell growth supplement (Sigma-Aldrich; Merck KGaA) and passaged as described previously (10).

Characterization of RAECs by immunofluorescence analysis. When the cells reached $80 \%$ confluence, the medium was drained, the cells were washed twice with PBS, fixed with $4 \%$ methanol for $30 \mathrm{~min}$, permeabilized with $0.1 \%$ Triton $\mathrm{X}-100$ for $15 \mathrm{~min}$ and washed three times with PBS successively. After incubation with $1 \%$ bovine serum albumin (BSA) (Beyotime Institute of Biotechnology, Haimen, China) for $1 \mathrm{~h}$. All above procedures were performed at room temperature. The cells were incubated overnight at $4^{\circ} \mathrm{C}$ with rabbit anti-rat factor VIII antibody (1:150 dilution; 65707; Cell Signaling Technologies, Inc., Danvers, MA, USA), followed by incubation with fluorescein isothiocyanate-labeled goat anti-rabbit immunoglobulin G antibody (A0562; 1:100 dilution; Beyotime Institute of Biotechnology) for $2 \mathrm{~h}$ at room temperature. Finally, the cells were washed three times with PBS and stained with DAPI (Sigma-Aldrich; Merck KGaA). Cells were observed and images were captured under an inverted fluorescence microscope.

Leptin treatment of RAECs. RAECs at passage 3 were cultured in a 6 -well plate at $5 \times 10^{5}$ cells/well in complete culture medium for 12 h. Leptin (P50596; R\&D Systems, Inc., Minneapolis, MN, USA) in a stock solution in PBS was added to the complete culture medium to achieve final concentrations of $0,10^{-10}, 10^{-9}$ or $10^{-8} \mathrm{M}$, followed by incubation for 36 or $48 \mathrm{~h}$. Each experimental condition was set up in triplicate.
Reverse-transcription quantitative polymerase chain reaction (RT-qPCR). Total RNA was obtained from RAECs by lysis with TRIzol (Invitrogen; Thermo Fisher Scientific, Inc.) for $10 \mathrm{~min}$ and extraction with chloroform, isopropanol and $75 \%$ ethanol. Complementary DNA was synthesized by using a PrimeScript RT Master mix kit (RR064A; Takara Bio Inc., Otsu, Japan). The primers used for PCR were as follows: Rat COX-2 forward, 5'-GCTTAAAGACCGCATCGAGGGTT-3' and reverse, 5'-GCATTGAGAGATGGGCTGTTGTGT-3'; rat 18S-ribosomal (r)RNA forward, 5'-GAATTCCCAGTA AGTGCGGGTCAT-3' and reverse, 5'-CGAGGGCCTCAC TAAACCATC-3'. PCR reactions were performed using a SYBR Premix Ex Taq II kit (RR82LR, Takara Bio, Inc.) in an ABI 7500 Real-Time PCR system (Applied Biosystems; Thermo Fisher Scientific, Inc.). Thermocyling conditions were as follows: $95^{\circ} \mathrm{C}$ for $30 \mathrm{sec}$; 40 cycles of $95^{\circ} \mathrm{C}$ for $5 \mathrm{sec}$ and $62^{\circ} \mathrm{C}$ for $30 \mathrm{sec} ; 95^{\circ} \mathrm{C}$ for $15 \mathrm{sec}, 60^{\circ} \mathrm{C}$ for $1 \mathrm{~min}$ and $95^{\circ} \mathrm{C}$ for $15 \mathrm{sec}$. COX-2 mRNA was normalized to the 18S-rRNA and relatively quantified by standard curve analysis; the $2^{-\Delta \Delta \mathrm{Cq}}$ method was used for quantification, as described previously (11).

Western blot analysis. Protein from RAECs was lysed with RIPA lysis buffer (WB0101; Biotech Well, Shanghai, China). The protein concentration was determined using a BCA protein quantification kit (23225; Shanghai Yu Bo Biological Technology Co., Ltd., Shanghai, China). Protein (50 $\mu \mathrm{g}$ per lane) was separated by $12 \%$ SDS-PAGE and then transferred onto a polyvinylidene difluoride membrane. After incubation with $3 \%$ BSA for $1 \mathrm{~h}$ at room temperature. 2 membranes (corresponding to 2 gels) were blotted with polyclonal rabbit anti-rat COX-2 antibody (1:1,000 dilution; 12282; Cell Signaling Technology, Inc.) and polyclonal rabbit anti- $\beta$-actin antibody (1:1,000 dilution; 4970; Cell Signaling Technology, Inc.) as a control overnight at $4^{\circ} \mathrm{C}$. The membranes were washed with Tris-HCl-buffered saline and re-blotted with secondary antibody (HRP-conjugated goat anti-rabbit antibody; 1:5,000; sc-2004; Santa Cruz Biotechnology, Inc., Dallas, TX, USA) at room temperature for $2 \mathrm{~h}$. Bands were displayed using a chemiluminescent reagent (P0018; Beyotime Institute of Biotechnology). Densitomtric analysis was performed with ImageJ software (version 1.46; National Institutes of Health, Bethesda, MD, USA).

ELISA for assessment of 6-keto $P G F_{1 \alpha}$ and $T X B_{2}$ protein secretion. The concentrations of 6-keto $\mathrm{PGF}_{1 \alpha}$ and $\mathrm{TXB}_{2}$ in the cell culture supernatant were detected by competitive ELISA (6-keto Prostaglandin F1 $\alpha$ ELISA kit; 515211; Cayman Chemical Co., Ann Arbor, MI, USA); and $\mathrm{TXB}_{2}$ ELISA kit (KGE011; R\&D Systems, Inc.) according to the manufacturer's instructions. Optical density (OD) values of 6-keto $\mathrm{PGF}_{1 \alpha}$ and $\mathrm{TXB}_{2}$ were read using an ELISA reader (Bio-Rad Laboratories, Inc., Hercules, CA, USA) at 405 or $450 \mathrm{~nm}$, respectively. According to the OD values and the formulas included in the instructions of the ELISA kits, the percentage of sample bound vs. maximum binding were calculated for standard and test samples.

Statistical analysis. Values are expressed as the mean \pm standard error of the mean and were analyzed by SPSS 17.0 statistical software (SPSS, Inc., Chicago, IL, USA). The 

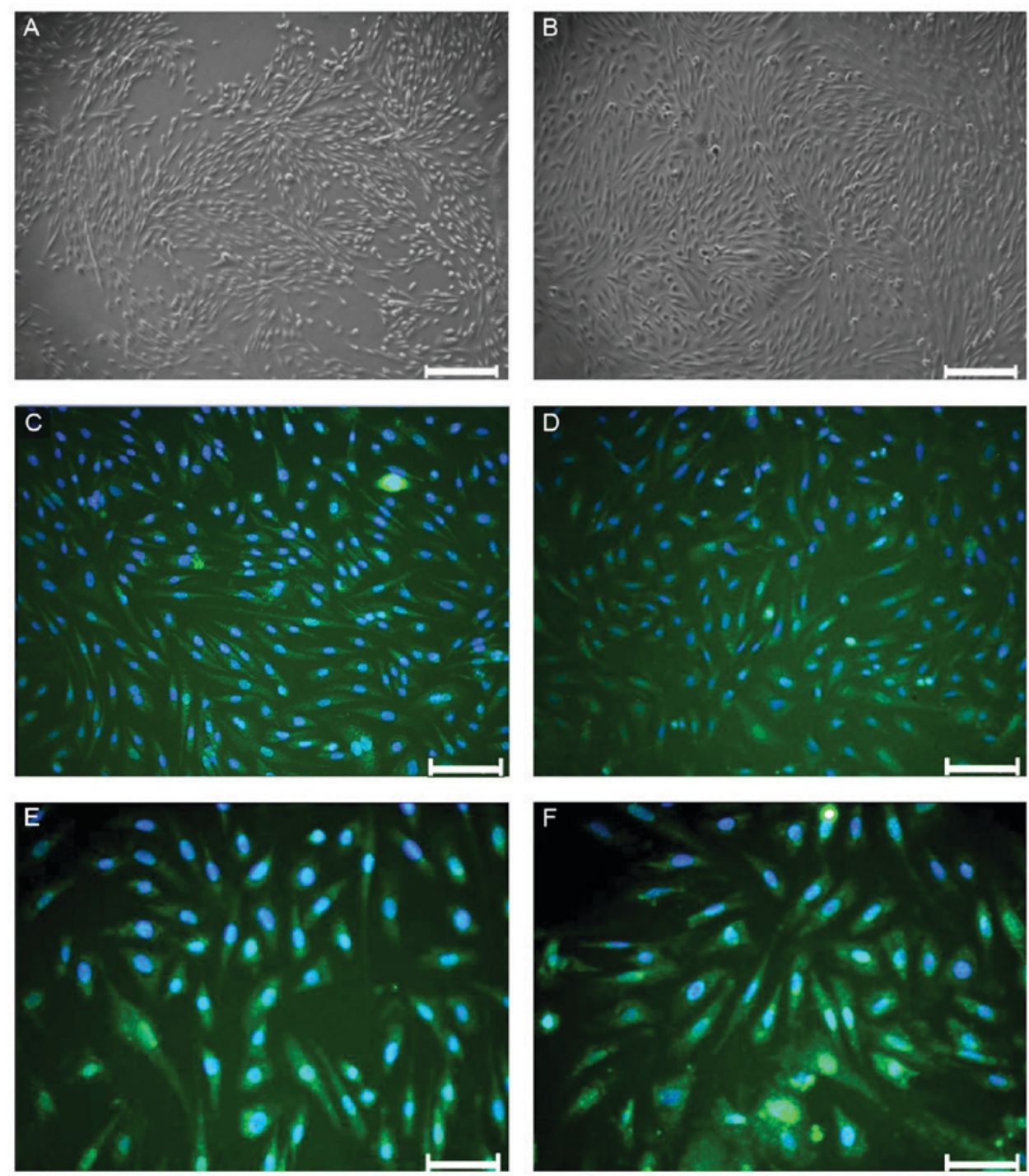

Figure 1. Culture and identification of RAECs. (A and B) Transmitted light images of (A) RAECs cultured for 6 days with cells presenting as shuttle-like or polygonal structures and (B) RAECs cultured for 10 days with cells having a cobblestone-like appearance (magnification, $\mathrm{x} 100$; scale bar, $200 \mu \mathrm{m}$ ) (C-F) Immunofluorescent staining for factor VIII on cells at 10 days, which is specifically expressed and displays in the cytoplasm as a green stain. Nuclei were counterstained with DAPI (blue). Magnification, x200 in (C) and (D); x400 in (E) and (F). Scale bar, $100 \mu \mathrm{m}$ in (C) and (D); $40 \mu \mathrm{m}$ in (E) and (F). RAECs, rat aortic endothelial cells.

statistical significance of differences among $\geq 3$ groups was determined by one-way analysis of variance followed by Dunn's post hoc analysis. Student's 2-tailed test was performed when only 2 groups were being compared. $\mathrm{P}<0.05$ was considered to indicate a statistically significant difference.

\section{Results}

Isolation, culture and identification of RAECs. At 6 days of primary culture, RAECs presented as shuttle-like or polygonal structures (Fig. 1A), and subsequently grew and integrated into a monolayer. After culture for 10 days, RAECs had a cobblestone-like appearance (Fig. 1B). Green fluorescence was observed in the cytoplasm under a fluorescence microscope after immunofluorescence staining with anti-factor VIII antibody, indicating EC-specific factor VIII expression in the cytoplasm. Expression of factor VIII was present in $\sim 90 \%$ of the cells (Fig. 1C-F).
Effects of leptin on COX-2 mRNA expression. RAECs treated with PBS were used as controls and they expressed low levels of COX-2 mRNA (Fig. 2). However, when RAECs were treated with different concentrations of leptin for different durations, the expression levels of COX-2 mRNA were increased. Although there was no statistical significance between the PBS group and that treated with the lowest concentration of leptin $\left(10^{-10} \mathrm{M}\right)$ at $36 \mathrm{~h}(\mathrm{P}=0.14)$, all other groups of RAECs treated with different concentrations of leptin for different durations exhibited a significantly increased expression of COX-2 mRNA $\left(\mathrm{P}<0.01 ; \mathrm{P}=0.003\right.$ for $10^{-9}$ or $10^{-8} \mathrm{M}$ leptin vs. PBS at $36 \mathrm{~h}$ ). Furthermore, these increases were dependent on the concentration of leptin and the incubation time (Fig. 2). Particularly after treatment with the high concentration of leptin $\left(10^{-8} \mathrm{M}\right)$ for $48 \mathrm{~h}$, the expression of COX-2 mRNA was significantly increased by up to 1.65 -fold compared with that in the PBS group $\left(\mathrm{P}<0.01 ; \mathrm{P}=0.002\right.$, leptin $10^{-10} \mathrm{M}$ vs. PBS; $\mathrm{P}<0.001$, leptin $10^{-9} \mathrm{M}$ vs. PBS; $\mathrm{P}=0.004$, leptin $10^{-8} \mathrm{M}$ vs. $\mathrm{PBS}$ at $48 \mathrm{~h}$ ). 
Table I. Effects of leptin treatment at different concentrations and for different durations on 6-keto-PGF $1 \alpha$ and TXB ${ }_{2}$ in the supernatant of cultured rat aortic endothelial cells.

\begin{tabular}{lccc}
\hline Time-point/group & 6-Keto $\mathrm{PGF}_{1 \alpha}(\mathrm{pg} / \mathrm{ml})$ & $\mathrm{TXB}_{2}(\mathrm{ng} / \mathrm{ml})$ & $\mathrm{TXB}_{2} / 6-\mathrm{keto} \mathrm{PGF}_{1 \alpha}$ \\
\hline $36 \mathrm{~h}$ & & & $59.48 \pm 12.89$ \\
PBS & $255.78 \pm 18.06$ & $15.07 \pm 3.47$ & $62.76 \pm 12.38$ \\
$10^{-10}$ M leptin & $259.11 \pm 30.22$ & $16.03 \pm 1.45$ & $49.18 \pm 11.15$ \\
$10^{-9}$ M leptin & $321.73 \pm 10.65^{\mathrm{a}}$ & $15.74 \pm 3.10$ & $39.99 \pm 5.60$ \\
$10^{-8}$ M leptin & $420.19 \pm 17.54^{\mathrm{b}}$ & $16.8 \pm 2.39$ & $65.48 \pm 7.79$ \\
$48 \mathrm{~h}$ & & & $60.38 \pm 4.61$ \\
PBS & $257.48 \pm 11.42$ & $16.85 \pm 2.03$ & $32.38 \pm 7.79^{\mathrm{b}}$ \\
$10^{-10}$ M leptin & $264.67 \pm 15.03$ & $15.98 \pm 1.55$ & $27.77 \pm 5.61^{\mathrm{b}}$ \\
$10^{-9}$ M leptin & $444.69 \pm 20.07^{\mathrm{b}}$ & $14.35 \pm 3.30$ & $17.43 \pm 3.95$ \\
$10^{-8}$ M leptin & $625.34 \pm 17.59^{\mathrm{b}}$ & & \\
\hline
\end{tabular}

${ }^{a} \mathrm{P}<0.05$ and ${ }^{\mathrm{b}} \mathrm{P}<0.01$ compared with $\mathrm{PBS}$ at the same time-point. $\mathrm{PG}$, prostaglandin; TX, thromboxane.

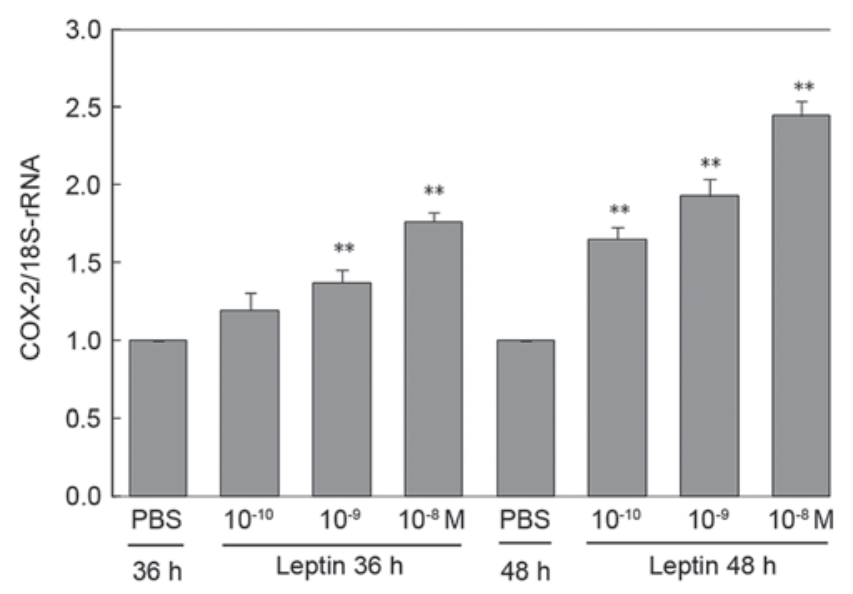

Figure 2. Effects of leptin treatment at different concentrations and for different durations on relative COX-2 mRNA expression by rat aortic endothelial cells. COX-2 mRNA expression was detected by reverse-transcription quantitative polymerase chain reaction analysis. ${ }^{* *} \mathrm{P}<0.01$ compared with the PBS group at the same time-point. COX, cyclooxygenase; rRNA, ribosomal RNA.

Effects of leptin on COX-2 protein expression. In agreement with the COX-2 mRNA results above, the expression of COX-2 protein was consistently decreased by RAECs treated with PBS (Fig. 3). Furthermore, the expression levels of COX-2 protein were concentration- and time-dependently increased by leptin. However, the increases at the protein level were not as significant as those at the mRNA level at $36 \mathrm{~h}$, as there was no statistical significance between the PBS group and the $10^{-10}$ or $10^{-9} \mathrm{M}$ leptin group ( $\left.\mathrm{P}>0.05\right)$; only at the high concentration, leptin $\left(10^{-8} \mathrm{M}\right)$ significantly upregulated COX-2 protein, namely by up to 2.64-fold of that of the PBS group $(\mathrm{P}<0.05$; $\mathrm{P}=0.135$, leptin $10^{-10} \mathrm{M}$ vs. $\mathrm{PBS} ; \mathrm{P}=0.072$, leptin $10^{-9} \mathrm{M}$ vs. $\mathrm{PBS}$; $\mathrm{P}=0.002$, leptin $10^{-8} \mathrm{M}$ vs. $\mathrm{PBS}$ at $36 \mathrm{~h}$ ). At $48 \mathrm{~h}$, the expression of COX-2 protein was similar to that of COX-2 mRNA, as all three concentrations of leptin led to a significant upregulation of COX-2 protein expression $\left(\mathrm{P}=0.007\right.$, leptin $10^{-10} \mathrm{M}$ vs. $\mathrm{PBS}$; $\mathrm{P}=0.004$ leptin $10^{-9} \mathrm{M}$ vs. $\mathrm{PBS} ; \mathrm{P}<0.001$, leptin $10^{-8} \mathrm{M}$ vs. PBS at 48 h; Fig. 3).
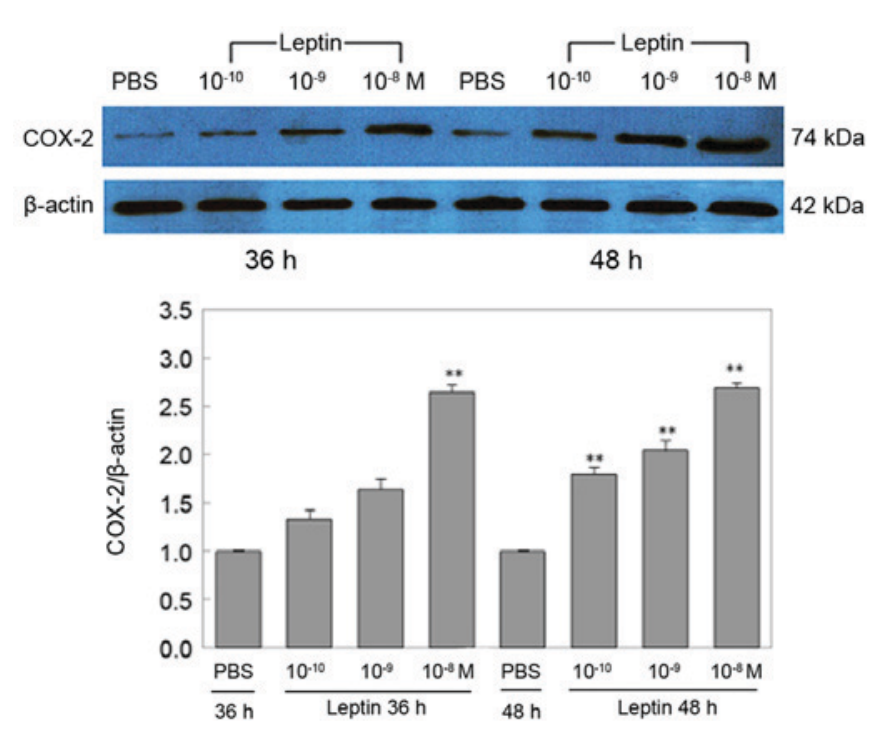

Figure 3. Effects of leptin treatment at different concentrations and for different durations on the relative expression of COX-2 mRNA by rat aortic endothelial cells. Representative western blot image presenting COX-2 protein expression. Quantitative expression values of COX-2 are presented in the bar graph. ${ }^{* *} \mathrm{P}<0.01$ compared with the PBS group at the same time-point. COX, cyclooxygenase.

Effects of leptin on 6-keto $P G F_{1 \alpha}$ and $T X B_{2}$. To explore the effects of leptin on the secretion of $\mathrm{COX}-2$ products 6-keto $\mathrm{PGF}_{1 \alpha}$ and $\mathrm{TXB}_{2}$, these proteins were detected in the cell culture supernatant by ELISA (Table I). At 36 and 48 h, the low concentration of leptin $\left(10^{-10} \mathrm{M}\right)$ had no significant effect on the levels of 6-keto $\mathrm{PGF}_{1 \alpha}$. However, the higher concentrations of leptin $\left(10^{-9}\right.$ and $\left.10^{-8} \mathrm{M}\right)$, particularly at the longer incubation time (48 h), produced significantly elevated levels of 6-keto $\mathrm{PGF}_{1 \alpha}(\mathrm{P}<0.05$; Table I). No significant effect on $\mathrm{TXB}_{2}$ was observed. However, the leptin concentrations of $10^{-9}$ or $10^{-8} \mathrm{M}$ significantly reduced the $\mathrm{TXB}_{2} / 6$-keto $\mathrm{PGF}_{1 \alpha}$ ratio at $48 \mathrm{~h}(\mathrm{P}<0.01$; Table $\mathrm{I})$. The purpose of calculating the ratio was to predict the effects of leptin on vascular systolic and diastolic function, as vasomotor function partly depends on this ratio. 


\section{Discussion}

Leptin is an endocrine hormone; in addition to inhibiting food intake and increasing energy consumption, it has a broad role in regulating biological functions, including immune, inflammation and hematopoietic functions. Studies have found that leptin participates in the occurrence and development of hypertension by activating the sympathetic nerve (12) as well as increasing renal $\mathrm{Na}^{+}-\mathrm{K}^{+}$-adenosine triphosphatase activity (13) and oxidative stress (14) in vivo. In vitro, leptin was found to act on endothelial cells by causing cell dysfunction (4), inflammatory injury (5) and endothelin-1 expression (6) to presumably participate in hypertension (3).

COX-2 is mainly expressed in ECs, macrophages and fibroblasts. It is generally accepted that when ECs are in inflammatory or pathological states, they increase the expression of COX-2 and therefore the production of its downstream products $\mathrm{PGI}_{2}$ and $\mathrm{TXA}_{2}$, which regulate vascular tension and platelet aggregation. The synthesis and release of $\mathrm{PGI}_{2}$ are mainly from ECs. $\mathrm{PGI}_{2}$ has a role in vasodilation and anti-platelet aggregation. The stable metabolite of $\mathrm{PGI}_{2}$ is 6-keto $\mathrm{PGF}_{1 \alpha}$. TX is an arachidonic hormone, which may occur in two major forms: $\mathrm{TXA}_{2}$ and $\mathrm{TXB}_{2}$. In vivo, $\mathrm{TXA}_{2}$ is mainly synthesized and secreted by the platelet microsomes and ECs, and has a strong effect on promoting vascular contraction and platelet aggregation (9). However, the biological half-life of $\mathrm{TXA}_{2}$ is only $30 \mathrm{sec}$, and is quickly converted into the inactive and stable metabolite $\mathrm{TXB}_{2}$. Therefore, the levels of 6-keto $\mathrm{PGF}_{1 \alpha}$ and $\mathrm{TXB}_{2}$ reflect the levels of $\mathrm{PGI}_{2}$ and $\mathrm{TXA}_{2}$; studying the effects of leptin on the expression of COX-2 and it downstream products may help to explain the pathogenesis of hypertension mediated by leptin. At the same time, it may also provide evidence for understanding the mechanisms of obesity-associated diseases.

In order to explore the effect of leptin on the expression of COX-2 and its downstream products $\mathrm{PGI}_{2}$ and TXA $\mathrm{T}_{2}, \mathrm{ECs}$ were separated from rat aortas and cultured. Factor VIII as a marker of ECs was detected by immunofluorescence staining. The results suggested that the purity of RAECs reached $\sim 90 \%$. After treatment of the RAECs, the expression levels of COX-2 mRNA and protein were significantly as well as leptin concentration- and time-dependently increased. The levels of 6-keto $\mathrm{PGF}_{1 \alpha}$ were increased by relatively high concentrations of leptin for the longer incubation time. Although the expression of $\mathrm{TXB}_{2}$ was not affected by leptin, the TXB2/6-keto PGF1 $\alpha$ ratio was increased after incubation with leptin at high concentrations and the longer incubation time. Thus, leptin upregulated the expression levels of the inflammation marker COX-2 and increased the vasodilator $\mathrm{PGI}_{2}$, while decreasing the ratio of $\mathrm{TXB}_{2}$ (vasoconstrictor substance) to $\mathrm{PGI}_{2}$. These results implied that leptin is associated with inflammation, while it enhanced endothelium-dependent vasorelaxation.

Studies have indicated that endothelium-dependent vasorelaxation mainly includes three pathways (15): i) Release of nitric oxide by activation of endothelial (e)NOS in the aorta; ii) release of endothelium-derived hyperpolarization factor in arteries with low resistance; and iii) stimulation of COX-2 to produce $\mathrm{PGI}_{2}$. Regarding the first two pathways associated with leptin, it has been confirmed that leptin promotes the expression of eNOS via phosphatidylinositol 3-kinase (16) and increases the release of EDHF (8). The latter pathway associated with leptin has remained to be fully elucidated, although leptin has been found to increase the expression of COX-2 (16,17). Manuel-Apolinar et al (17) found that leptin is involved in the inflammatory response by increasing the expression of intercellular adhesion molecules and COX-2 on murine aorta tissue mediated by the long leptin receptor. Garonna et al (18) found that the pro-angiogenic actions of leptin required a functional endothelial p38 mitogen-activated protein kinase/Akt/COX-2 signaling axis. To the best of our knowledge, the effects of different doses of leptin on COX-2 and its downstream products 6-keto $\mathrm{PGF}_{1 \alpha}$ and $\mathrm{TXB}_{2}$ have remained elusive. The results of the present study provided direct evidence to answer this question.

As selective COX-2 inhibitors, non-steroidal anti-inflammatory drugs, such as aspirin and celecoxib, are widely used, which have anti-inflammatory analgesic effects. At different stages of hypertension and atherosclerotic plaque formation, ECs may highly express COX-2. A selective COX-2 inhibitor was able to reduce inflammation and platelet aggregation, resulting in a decrease of the incidence of cardiovascular events and a protective effect on the cardiovascular system $(19,20)$. However, when taking such medication at large dosages for a long time, patients present with various types of complications, the most common of which is digestive tract damage. Importantly, adverse effects on the cardiovascular system have been reported for prostanoid inhibition by COX-2 inhibitors: Certain studies have demonstrated that COX-2 inhibitors may increase the risk of cardiovascular events, such as myocardial infarction and stroke (21). Therefore, the effects of COX-2 inhibitors on the cardiovascular system require re-analysis; consistently with the results of the present study, COX-2 inhibitors may increase the risk of hypertension.

In conclusion, the present study investigated the effects of leptin on the expression of COX-2 and it downstream products 6-keto $\mathrm{PGF}_{1 \alpha}$ and $\mathrm{TXB}_{2}$ from RAECs. Treatment with leptin, a mediator of hypertension, was identified to significantly upregulate the expression of COX-2, a mediator of inflammation, and the levels of its vasodilator product 6-keto $\mathrm{PGF}_{1 \alpha}$, while downregulating the ratio of the vasoconstrictor $\mathrm{TXB}_{2}$ to 6-keto $\mathrm{PGF}_{1 \alpha}$, suggesting that leptin may promote cardiovascular diseases by increasing the expression of COX-2. However, elective COX-2 inhibitors may not provide a benefit for leptin-mediated cardiovascular diseases, as they may rather increase the occurrence of hypertension due to inhibiting vasodilator 6-keto $\mathrm{PGF}_{1 \alpha}$, a downstream product of COX-2, as well.

\section{Acknowledgements}

The present study was funded by grants from the Science and Technology Plan Project of Guangzhou city in China (grant no. 201510010181), the Science and Technology Plan Project of Guangdong Province in China (grant nos. 2014A020212364 and 2013B021800282) and the Guangdong Natural Science Foundation in China (grant nos. 2015A030313467 and S2013010015962).

\section{References}

1. Münzberg $\mathrm{H}$ and Morrison CD: Structure, production and signaling of leptin. Metabolism 64: 13-23, 2015. 
2. Wada N, Hirako S, Takenoya F, Kageyama H, Okabe M and Shioda S: Leptin and its receptors. J Chem Neuroanat 61-62: 191-199, 2014.

3. Kang YS: Obesity associated hypertension: New insights into mechanism. Electrolyte Blood Press 11: 46-52, 2013.

4. Artwohl M, Roden M, Hölzenbein T, Freudenthaler A, Waldhäusl W and Baumgartner-Parzer SM: Modulation by leptin of proliferation and apoptosis in vascular endothelial cells. Int J Obes Relat Metab Disord 26: 577-580, 2002.

5. Singh P, Hoffmann M, Wolk R, Shamsuzzaman AS and Somers VK Leptin induces C-reactive protein expression in vascular endothelial cells. Arterioscler Thromb Vasc Biol 27: e302-e307, 2007.

6. Quehenberger P, Exner M, Sunder-Plassmann R, Ruzicka K, Bieglmayer C, Endler G, Muellner C, Speiser W and Wagner O: Leptin induces endothelin-1 in endothelial cells in vitro. Circ Res 90: 711-718, 2002.

7. Benkhoff S, Loot AE, Pierson I, Sturza A, Kohlstedt K, Fleming I, Shimokawa H, Grisk O, Brandes RP and Schröder K: Leptin potentiates endothelium-dependent relaxation by inducing endothelial expression of neuronal NO synthase. Arterioscler Thromb Vasc Biol 32: 1605-1612, 2012.

8. Lembo G, Vecchione C, Fratta L, Marino G, Trimarco V, d'Amati G and Trimarco B: Leptin induces direct vasodilation through distinct endothelial mechanisms. Diabetes 49: 293-297, 2000 .

9. Santovito D, Mezzetti A and Cipollone F: Cyclooxygenase and prostaglandin synthases: Roles in plaque stability and instability in humans. Curr Opin Lipidol 20: 402-408, 2009.

10. Kobayashi M, Inoue K, Warabi E, Minami T and Kodama T: A simple method of isolating mouse aortic endothelial cells. J Atheroscler Thromb 12: 138-142, 2005.

11. Livak KJ and Schmittgen TD: Analysis of relative gene expression data using real-time quantitative PCR and the 2(-Delta Delta C(T)) method. Methods 25: 402-408, 2001.

12. Shek EW, Brands MW and Hall JE: Chronic leptin infusion increases arterial pressure. Hypertension 31: 409-414, 1998.
13. Beltowski J: Leptin and the regulation of renal sodium handling and renal na-transporting ATPases: Role in the pathogenesis of arterial hypertension. Curr Cardiol Rev 6: 31-40, 2010.

14. Wojcicka G, Jamroz-Wiśniewska A, Widomska S, Ksiazek M and Bełtowski J: Role of extracellular signal-regulated kinases (ERK) in leptin-induced hypertension. Life Sci 82: 402-412, 2008.

15. Durand MJ and Gutterman DD: Diversity in mechanisms of endothelium-dependent vasodilation in health and disease. Microcirculation 20: 239-247, 2013.

16. Vecchione C, Maffei A, Colella S, Aretini A, Poulet R, Frati G, Gentile MT, Fratta L, Trimarco V, Trimarco B and Lembo G: Leptin effect on endothelial nitric oxide is mediated through Aktendothelial nitric oxide synthase phosphorylation pathway. Diabetes 51: 168-173, 2002.

17. Manuel-Apolinar L, Lopez-Romero R, Zarate A, Damasio L, Ruiz M, Castillo-Hernández C, Guevara G and Mera-Jiménez E: Leptin mediated $\mathrm{ObRb}$ receptor increases expression of adhesion intercellular molecules and cyclooxygenase 2 on murine aorta tissue inducing endothelial dysfunction. Int J Clin Exp Med 6: 192-196, 2013.

18. Garonna E, Botham KM, Birdsey GM, Randi AM, GonzalezPerez RR and Wheeler-Jones CP: Vascular endothelial growth factor receptor-2 couples cyclo-oxygenase- 2 with pro-angiogenic actions of leptin on human endothelial cells. PLoS One 6: e18823, 2011.

19. Rahme E, Pilote L and Lelorier J: Association between naproxen use and protection against acute myocardial infarction. Arch Intern Med 162: 1111-1115, 2002.

20. De Vecchis R, Baldi C, Di Biase G, Ariano C, Cioppa C, Giasi A, Valente $\mathrm{L}$ and Cantatrione S: Cardiovascular risk associated with celecoxib or etoricoxib: A meta-analysis of randomized controlled trials which adopted comparison with placebo or naproxen. Minerva Cardioangiol 62: 437-448, 2014

21. Mcgettigan P and Henry D: Cardiovascular risk with non-steroidal anti-inflammatory drugs: systematic review of population-based controlled observational studies. PLoS Med 8: e1001098, 2011. 